\title{
Leukotriene A-4 Hydrolase
}

National Cancer Institute

\section{Source}

National Cancer Institute. Leukotriene A-4 Hydrolase. NCI Thesaurus. Code C116951.

Leukotriene A-4 hydrolase (611 aa, $69 \mathrm{kDa}$ ) is encoded by the human LTA4H gene. This protein plays a role in the conversion of leukotriene A4 to leukotriene B4. 